\title{
Pelatihan Penyusunan Laporan Keuangan pada BUMDes Desa Balesari
}

\author{
Kartika Pradana Suryatimur, Siti Afidatul Khotijah, Panji Kusuma Prasetyanto \\ Fakultas Ekonomi, Universitas Tidar \\ email: kpsuryatimur@untidar.ac.id
}

\begin{abstract}
This community service program aims to provide an understanding of financial reports to BUMDes administrators. This program is implemented for BUMDes management in Balesari Village, Windusari District, Magelang Regency, Central Java Province. The service method used is training and discussion. The result of this activity is that BUMDes administrators can understand and prepare financial reports well. Previously, BUMDes management only recorded cash disbursements and income, did not classify transactions that occurred, so that the financial reports could not provide appropriate financial information. By having a basic understanding of accounting, BUMDes management can classify each transaction and record it according to the account, so that BUMDes' financial reports are tidier and can provide good information to their users.
\end{abstract}

Keywords: Financial Report, BUMDes

\begin{abstract}
Abstrak
Program pengabdian kepada masyarakat ini bertujuan untuk memberikan pemahaman tentang laporan keuangan kepada pengurus BUMDes. Program ini dilaksanakan kepada pengurus BUMDes Desa Balesari Kecamatan Windusari, Kabupaten Magelang, Provinsi Jawa Tengah. Metode pengabdian yang digunakan adalah pelatihan dan diskusi. Hasil kegiatan adalah pengurus BUMDes dapat memahami dan menyusun laporan keuangan dengan baik. Sebelumnya pengurus BUMDes hanya melakukan pencatatan pengeluaran dan pemasukan kas, tidak melakukan klasifikasi atas transaksi yang terjadi, sehingga laporan keuangan tidak dapat memberikan informasi keuangan yang sesuai. Dengan memiliki pemahaman dasar tenatng Akuntansi yang pegurus BUMDes dapat mengklasifikasikan setiap transaksi dan mencatat sesuai dengan akun, sehingga laporan keuangan BUMDes menjadi lebih rapi dan dapat memberikan informasi yang baik kepada pengguannya.
\end{abstract}

Kata Kunci : Laporan Keuangan, BUMDes

\section{PENDAHULUAN}

Desa menjadi agen terdepan pemerintah untuk mewujudkan tujuan pembangunan nasional. Badan Usaha Milik Desa (BUMDes) berperan sebagai sarana untuk menjangkau kelompok, sasaran riil untuk disejahterakan. Permendagri nomor 39 tahun 2010 tentang badan usaha milik desa menyebutkan Bumdes didirikan untuk meningkatkan kemampuan keuangan pemerintah desa dalam penyelenggaraan pemerintahan dan meningkatkan pendapatan masyarakat sesuai dengan kebutuhan dan potensi desa. Pendirian, tata kelola, dan pengelolaan
Bumdes disesuaikan dengan peraturan pemerintah daerah [1].

BUMDes menjadi salah satu harapan masyarakat untuk dapat meningkatkan kesejahteraannya. Melalui BUMDes diharapkan berbagai elemen masyarakat yang ada pada wilayah desa dapat tergerak untuk menggali potensi di wilayahnya. Tempat wisata alam, wisata spiritual, kerajinan tradisinal, dan kearifan lokal dapat menjadi daya jual untuk dipromosikan. Tentunya potensi-potensi yang ada harus didukung dengan Sumber Daya Manusia yang unggul untuk mengelolanya. 
Kementerian Desa, Pembangunan Daerah Tertinggal dan Transmigrasi mengumumkan hingga pertengahan tahun 2018, jumlah Badan Usaha Milik Desa (BUMDes) di seluruh Indonesia mencapai 35 ribu [2]. Namun dari banyaknya BUMDes tersebut banyak yang belum maksimal dalam operasionalnya. Ada beragam masalah yang membuat ribuan BUMDes belum tumbuh sebagaimana harapan. Pertama, karena wacana BUMDes bagi banyak desa baru masih seumur jagung terutama sejak disahkannya UU Desa No. 6 Tahun 2014 tentang Desa. Kedua, selama bertahun-tahun desa adalah struktur pemerintahan yang berjalan atas dasar instruksi dari lembaga di atasnya. Pengesahan UU Desa, Nawacita dan kemudian dana desa memang amunisi baru yang membuat desa memiliki kekuatan besar membangun diri. Tetapi di sisi lain ini adalah tantangan yang benar-benar berbeda dari sejarah desa sebelumnya. Saat ini desa sepenuhnya memiliki wewenang untuk merumuskan langkahnya sendiri melalui Musyawarah Desa. Kesempatan tersebut harus bisa dimanfaatkan oleh desa dalam mengembangkan unit usahanya, salah satunya adalah Desa Balesari.

Desa Balesari terletak di Kecamatan Windusari, Kabupaten Magelang, Provinsi Jawa Tengah. Letak geografis yang berada di kaki Gunung Sumbing menjadikan wilayah Desa Balesari dikelilingi bukit dan pesona alam yang indah dan alami. Hal itu menjadi daya tarik Desa Balesari, dengan memanfaat-kan keindahan alam sebagai tempat wisata dan komoditas kopi yang tumbuh di sekitar desa sebagai keunggulan. Tempat wisata dan pengolahan kopi dikelola oleh BUMDes Desa Balesari, termasuk di dalamnya pengelolaan pem-bukuan dan pencatatan laporan keuangan.

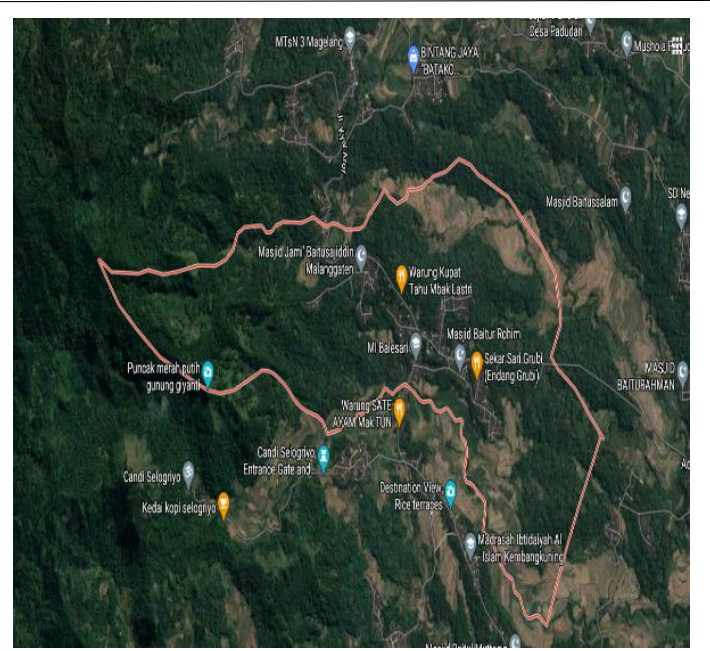

Gambar 1. Peta Lokasi BUMDes Balesari.

Penyusunan laporan keuangan pada setiap entitas perlu dilaksanakan, tidak terkecuali pada BUMDes. Laporan keuangan menjadi gambaran penting di dalam melihat posisi keuangan dan kinerja keuangan. Laporan keuangan adalah suatu penyajian terstruktur dari posisi keuangan dan kinerja keuangan suatu entitas [3]. Tujuan dari laporan keuangan adalah untuk memberikan informasi mengenai posisi keuangan, kinerja keuangan dan arus kas entitas yang bermanfaat bagi sebagian besar pengguna laporan keuangan dalam pembuatan keputusan ekonomi [4]. Laporan keuangan yang baik dapat meningkatkan kesempatan entitas untuk mendapatkan kepercayaan dari kreditur [5].

BUMDes Desa Balesari belum melakukan pencatatan dengan baik dan layak, sehingga laporan keuangan yang dimiliki tidak informatif dan sulit dimengerti oleh pembacanya. Pencatatan pembukuan hanya berdasarkan kas masuk dan keluar tanpa ada klasifikasi akun yang jelas. Pencatatan modal dalam BUMDes juga tidak jelas, sehingga dapat berpotensi menyebabkan salah tafsir dalam membaca laporan keuangan.

Program pengabdian masyarakat ini bertujuan memberikan pelatihan pembukuan kepada pengelola BUMDes. Pelatihan dilakukan guna memberikan pemahaman serta agar dapat diterapkan 
pada proses pencatatan pembukan setiap transaksi BUMDes. Pelatihan ini diharapkan dapat memberikan kontribusi dalam proses penyusunan laporan keuangan BUMDes Desa Balesari agar lebih baik dan menjadi layak. Adanya laporan keuangan yang baik akan berdampak pada kualitas informasi yang disajikan, dengan demikan para pengguna dapat membuat keputusan yang baik. Peningkatan kualitas laporan keuangan dapat meningkatkan kepercayaan perbankan dalam memberikan pembiayaan kepada unit kerja BUMDes [6].

\section{METODE PENGABDIAN}

Metode yang diterapkan pada kegiatan pengabdian kepada masyarakat tampak pada gambar 1. Pada gambar tersebut terdapat tiga tahapan kegiatan yang dilaksanakan sebagai rangkaian dari program pengabdian kepada masyarakat. Tahapan kegiatan tersebut dilaksanakan secara runtut dan sistematis guna memaksimalkan output kegiatan.

Identifikasi masalah yang

dihadapi BUMDes Balesari

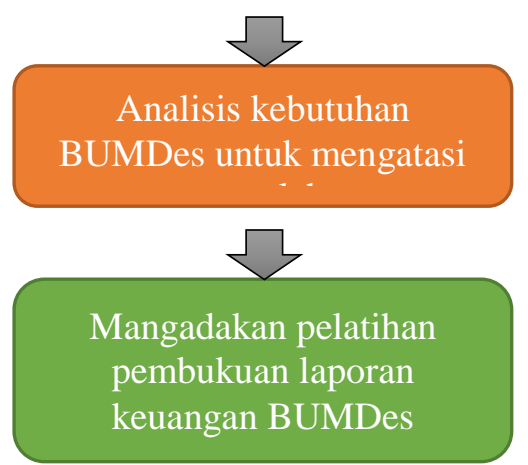

Gambar 2. Pelaksanaan Kegiatan

Metode yang dilaksanakan disesuaikan untuk dapat menyelesaikan masalah mitra. Identifikasi masalah dilakukan dengan wawancara kepada pengelola BUMDes dan pengelola unit kerja untuk menyimpulkan masalah yang perlu diprioritaskan untuk diselesaikan. Tim pengabdian melakukan analisis kebutuhan kemudian merumuskan solusi untuk membantu penyelesaian masalah yang dihadapi mitra. Solusi pemecahan masalah berupa pelatihan pembukuan laporan keuangan untuk pengurus BUMDes dan pengurus unit kerja.

Kegiatan pelatihan pembukan laporan keuangan dilaksanakan dengan menggunakan metode ceramah. Pelatihan ini bertujuan untuk memberikan pengetahuan dan pemahaman tentang pencatatan transaksi dan menyusun laporan keuangan BUMDes yang baik dan informative. Peserta pelatihan ialah seluruh pengurus unit kerja dan BUMDes. Pelaksanaan kegiatan ini diharapkan pengurus BUMDes dapat melakukan pencatatan transaksi dan penyusunan laporan keuangan yang baik.

\section{HASIL DAN PEMBAHASAN}

Pelaksanaan rangkaian Program pengabdian kepada masyarakat dilaksanakan di Balai Desa Balesari Kecamatan Windusari Kabupaten Magelang. Koordinasi awal dilakukan pada 20 Juli 2020 di Bukit Giyanti yang juga menjadi salah satu unit usaha wisata BUMDes Balesari. Kegiatan koordinasi awal dihadiri oleh direktur BUMDes dan beberapa pengurus unit usaha di bawah pengelolaan BUMDes. Pada saat koordinasi direktur dan pengurus unit usaha BUMDes menjelaskan kegiatan bisnis dan kendala yang dihadapi oleh pengurus. Kemudian hasil dari koordinasi awal disepakati pelaksanaan kegiatan pengabdian berupa pelatihan pencatatan transaksi dan penyusunan laporan keuangan BUMDes.

Gambar 2. Kegiatan pelatihan penyusunan laporan keuangan BUMDes. 


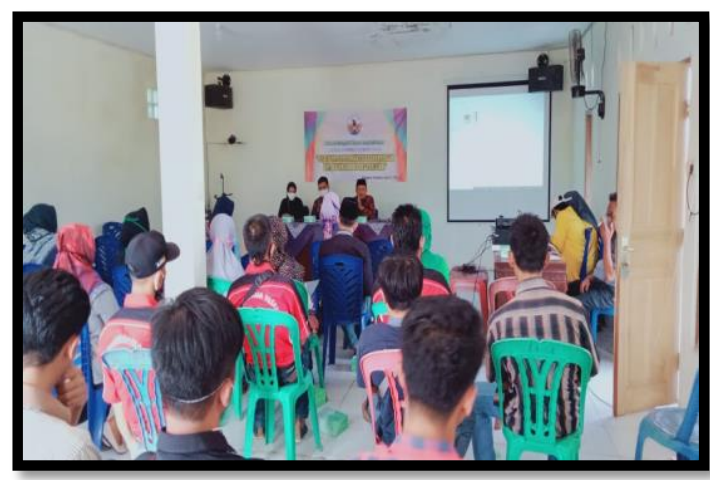

Gambar 3. Kegiatan pelatihan penyusunan laporan keuangan BUMDes.

Kegiatan pengabdian dilaksanakan bulan Maret sampai dengan bulan Oktober. Pelatihan pencatatan dan penyusunan laporan keuangan dilaksanakan di Balai Desa Balesari. Pelaksanaan kegiatan berjalan dengan baik dan lancar. Peserta pelatihan yang merupakan pengurus unit usaha dari BUMDes Balesari antusias dan fokus menyimak penjelasan dari narasumber.

Pelatihan pencatatan transaksi dan penyusunan laporan keuangan BUMDes menyampaikan materi tentang klasifikasi akun dan pencatatan transaksi secara sederhana. Dengan berbekal pengetahuan dan pemahaman kedua materi tersebut diharapkan pengurus BUMDes dapat menyusun laporan keuangan yang baik.

\section{SIMPULAN}

Kegiatan pelatihan penyusunan laporan keuangan pada BUMDes Desa Balesari telah dilaksanakan dengan baik dan lancar. Pengurus BUMDes antusias dalam mengikuti pelatihan, serta aktif untuk berdiskusi dengan pemateri. Dengan adanya pelatihan ini pengurus BUMDes memiliki pemahaman tentang dasar Akuntansi untuk melakukan penyusunan laporan keuangan yang memadai. Manfaat lain dari pelatihan ini yakni, pengurus BUMDes dapat mempertanggungjawabkan kegiatannya, salah satunya dengan melalui laporan keuangan.

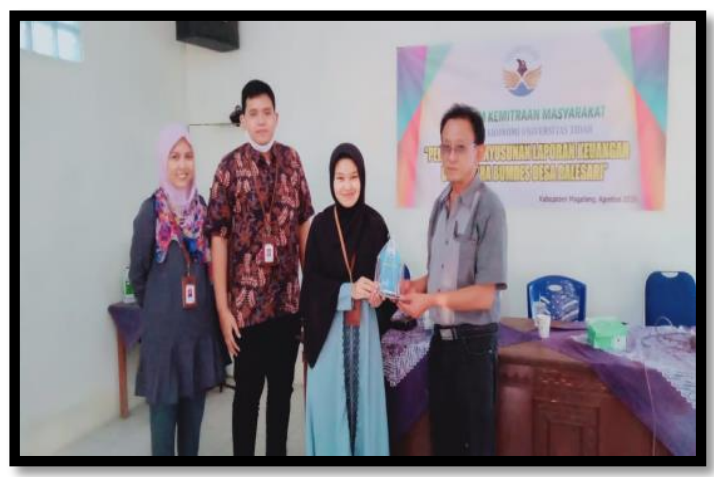

Gambar 4. Penyerahan plakat program pengabdian kepada masyarakat kepada Direktur BUMDes Desa Balesari

\section{UCAPAN TERIMAKASIH}

Terimakasih kami sampaikan kepada Lembaga Penelitian dan Pengabdian Masyarakat (LPPM) Uuniversitas Tidar yang telah membiayai seluruh rangkaian program pengabdian masyarakat. Terimakasih juga kami sampaikan kepada seluruh pengurus BUMDes Desa Balesari sebagai mitra kegiatan. Kemudian kami juga sampaikan terimakasih kepada seluruh pihak yang mendukung terlaksananya program pengabdian kepada masyarakat ini.

\section{DAFTAR PUSTAKA}

[1] C. B. Ramadana, H. Ribawanto, and Suwondo, "Keberadaan Badan Usaha Milik Desa (Bumdes) Sebagai Penguatan Ekonomi Desa (Studi di Desa Landungsari, Kecamatan Dau, Kabupaten Malang)," J. Adm. Publik, vol. 1, no. 6, 2013.

[2] Berdesa, "Informasi Lengkap Tentang BUMDes Yang Harus Anda Ketahui," 2018. .

[3] IAI, Standar Akuntansi Keuangan. Jakarta, 2007.

[4] Risal, W. Renny, and Jaurino, "Pendampingan Akuntansi Dan Keuangan BUMDes Sedahan Jaya Kecamatan Sukadana Kabupaten Kayong Utara," Cendekia J. 
Pengabdi. Masy., vol. 2, no. 1, pp. 49-57, 2020.

[5] T. Rahmawati and O. R. Puspasari, "Implementasi SAK ETAP dan Kualitas Laporan Keuangan UMKM Terhadap Akses Modal Perbankan," J. Kaji. Akunt., vol. 1, no. 1, 2017.

[6] R. Rudianto and S. V. Siregar, "Kualitas Laporan Keuangan UMKM Serta Prospek Impelentasi SAK ETAP," J. Akunt. dan Keuang. Indones., vol. 9, no. 1, 2012. 